УДК 338.242.2: 656.078.89

JEL D25, L26, L91, M21, O29

DOI 10.31375/2226-1915-2020-4-92-107

\section{ЦІЛІ ТА МЕТОДИ ОЦІНКИ БІЗНЕСУ У МОРСЬКІЙ ГАЛУЗІ}

\author{
Н.Г. Гребенник \\ канд. економ. наук, дочент \\ кафедри «Підприсмництво та туризм» \\ nataly.grebennyk@gmail.com \\ https://orcid.org/0000-0002-1554-0697 \\ Е.Г. Восканян \\ студентка магістратури спечіальност \\ «Підприємниитво, торгівля \\ та біржова діяльність» \\ emmavosk1998@gmail.com \\ Одеський національний \\ морський університет, Одеса, Украӥна
}

Анотація. У багатьох праиях описаний прочес оцінки бізнесу. У більшості робіт вказу ється, що основна мета процесу оцінки - виявити критично важливі області бізнесу, шо створюють цінність. С низька робіт, у яких досліджено методичні основи очінки вартості об 'єктів власності, а також відображено проблеми існуючих підходів до оцінки об'єктів власності в морських портах. Але відсутні комплексні дослідження оцінки бізнесу в інших секторах морської галузі, наприклад, таких як сервісне берегове обслуговування.

Метою роботи є дослідження иілей та методів оиінки вартості бізнесу в різних сферах морської галузі з врахуванням специфіки їх господарювання.

Оиінка бізнесу - иее багаторівневий складний прочес. Під час оцінки бізнесу необхідно прове сти ревізію та іноді переоцінити всі активи компанії $i$ побудувати прогнози на певний часовий інтервал.

Визначення вартості бізнесу комплексний прочес, який вимагає врахування ряду факторів $i$ аналіз фінансового стану бізнесу.

У статті досліджені ситуачії коли власник зобов'язаний виконати оичнку майна, та ситуаиії коли ие рекомендується зробити.

При оцінці бізнесу в морській галузі треба брати до уваги існуючи методи та підходи, але бізнес як об'єкт оиінки потребуе іншого сполу чення традииійних методів доходного, порівняльного та витратного підходів, та використання конкретних методів оцінки саме бізнесу й з враху ванням специфіки господарювання окремих секторів морської галузі.

Ключові слова: бізнес, оичнка бізнесу, оцінка вартості, процес оцінки, морська галузь.

(C) Гребенник Н.Г., Восканян Е.Г., 2020
УДК 338.242.2: 656.078.89

JEL D25, L26, L91, M21, O29

DOI 10.31375/2226-1915-2020-4-92-107

\section{ЦЕЛИ И МЕТОДЫ ОЦЕНКИ БИЗНЕСА В МОРСКОЙ ОТРАСЛИ}

\author{
Н.Г. Гребенник \\ канд. эконом. наук, доиент кафедры \\ «Предпринимательство и туризм» \\ nataly.grebennyk@gmail.com \\ https://orcid.org/0000-0002-1554-0697 \\ Э.Г. Восканян \\ студентка магистратуры специальности \\ «Предпринимательство, торговля \\ и биржевая деятельность» \\ emmavosk1998@gmail.com
}

Одесский национальный морской университет, Одесса, Украина

Аннотация. Во многих работах описан процесс оченки бизнеса. В большинстве публикаций указывается, что основная иель процесса оценки выявить критически важные области бизнеса, которые создают иенность. Есть часть работ, в которых исследованы методические основы оценки стоимости объектов собственности, а также отражены проблемы существвющих подходов к оченке объектов собственности в морских портах. Но отсутствуют комплексные исследования оценки бизнеса в других секторах морской отрасли, например, таких как сервисное береговое обслуживание.

Целью работы является исследование челей и методов оценки стоимости бизнеса в различных сферах морской отрасли с учетом специфики их хозяйствования. Оиенка бизнеса - это многоуровневый сложный процесс. При оценке бизнеса необходимо провести ревизию и иногда переоченить все активы компании и построить прогнозы на определенный временной интервал.

Определение стоимости бизнеса - это комплексный процесс, который требует учета ряда факторов и анализа финансового состояния бизнеса.

В статье исследованы ситуачии, когда владелеи обязан выполнить оченку имущества, $u$ ситуации, когда это только рекомендуется сделать.

При оценке бизнеса в морской отрасли надо принимать во внимание существуюшие методы $и$ подходы, но бизнес как объект оценки требует иного обобщения традиционных методов доходного, сравнительного и затратного подходов, $u$ использование конкретных методов оценки именно бизнеса и с учетом специфики хозяйствования отдельных секторов морской отрасли.

Ключевые слова: бизнес, оценка бизнеса, оценка стоимости, прочесс оченки, морская отрасль. 
UDC 338.242.2: 656.078.89

JEL D25, L26, L91, M21, O29

DOI 10.31375/2226-1915-2020-4-92-107

\title{
OBJECTIVES AND METHODS OF BUSINESS VALUATION IN THE MARITIME INDUSTRY
}

\author{
Natalia Grebennyk \\ PhD, Docent of Department «Entrepreneurship and tourism» \\ nataly.grebennyk@gmail.com \\ https://orcid.org/0000-0002-1554-0697 \\ Emma Voskanian \\ graduate student «Entrepreneurship, trade and exchange activity» \\ emmavosk1998@gmail.com \\ Odessa National Maritime University, Odessa, Ukraine
}

\begin{abstract}
The business appraisal process is described in many works. It states that the main purpose of the assessment process is to identify critical business areas that create value. In which publications are investigated the methodological foundations for assessing the value of property. The problems of different approaches to the assessment of property objects in seaports are described. But there is a lack of comprehensive business valuation studies in other sectors of the maritime industry, such as onshore services.

The aim of the work is to study the goals and methods of assessing the value of a business in various areas of the maritime industry, taking into account their specifics.

Business valuation is a multilevel complex process. When evaluating a business, it is necessary to audit and sometimes revalue all the assets of the company. It is necessary to build forecasts for a certain time interval.

Before starting the business appraisal process, it is necessary to take into account certain key factors: economic factors (profitability and risks), political factors (lack of a stable and predictable situation in the industry), social factors (personal reasons of customers and consumers of appraisal), information factors (for correct estimates need reliable information).

The need to assess the value of a business arises in almost all transformations: when buying and selling an enterprise, its corporatization, mergers and acquisitions, as well as in many other situations.

There are situations when the need to assess those specified in the law. Basically, these cases concern the appraisal of state property.

There are many other situations where an assessment needs to be made. These include: buying - selling a company, making management decisions, determining the amount of tax on the company's property, insuring the company's property, obtaining a loan, investing.

A properly performed appraisal is also a monitoring of the company's performance and revaluation of the property's value. Therefore, it is important to ensure that the financial data to be evaluated is complete, current and accurate. Only with reliable data and a well-planned strategic approach can a reliable forecast be made. The more complete and detailed the data for analysis are, the more accurate and qualitative the results of the assessment will be.

The most common valuation method is the discounted cash flow method. Its advantage is the ability to measure future results today. This is a complex expert method, but it provides information about the business prospects.
\end{abstract}


When assessing a business in the maritime industry, it is necessary to take into account the existing methods and approaches, but business as an object of assessment requires a different message from the traditional methods of profitable, comparative and cost-based approaches, and the use of specific methods for assessing the business and taking into account the specifics of the management of individual sectors of the maritime industry.

Keywords: business, business valuation, valuation, evaluation process, the maritime industry.

Постановка проблеми. За визначенням оцінка бізнесу $є$ встановленням вартості функціонуючого підприємства. Це вкрай важливо як при покупці або продажі компанії, так і для іï поточного управління. Оцінка бізнесу сьогодні стає все більш важливою при прийнятті менеджментом компаній управлінських рішень. Для будь-якої компанії вона може стати базовим інструментом планування i управління. Грамотне використання результатів оцінки спроможне підвищити ефективність використання ресурсів компанії і забезпечити більш високий рівень іï економічної безпеки.

Важливо відрізняти вартість компанії від іiі ціни. Ціна є сума коштів, за яку було продано компанію. Тобто це значення з'являється лише у момент продажу, і залежить в основному від попиту і пропозицій на ринку в даний момент. Вартість компанії - це те, що кожен потенційний покупець дає компанії в залежності від свого профілю і інтересів. Це грошова міра того, наскільки корисною буде компанія для цієї людини.

Нажаль багато власників бізнесу i ТОП-менеджерів недооцінюють інформацію про вартість бізнесу, та не розуміють сам процес оцінки, який являє собою складний багатоетапний процес 3 обов'зковим використанням різних методів та підходів. Незалежно від обраного методу, оцінка бізнесу - це процес, у якому вимірюються (кількісно та якісно) елементи (складові) компанії, що генерують поточну вартість, а також аналізується іï конкурентне становище та фінансові маркери. Базовий метод оцінки, який використовується, буде залежати від таких факторів, як галузь, в якій працює компанія, розмір компаніі, очікуваний грошовий потік і тип продукту або послуги, які вона пропонує.

Процес оцінки за своєю суттю $є$ складним організаційно-методичним комплексом, тому життєво важливо, щоб оцінювач мав необхідну кваліфікацію як у сфері оціночної діяльності, так і в галузі, в якій працює компанія. Оцінювач повинен знати бізнес-модель компанії, ऑii стратегію, добре розуміти ринок, на якому вона працює, і елементи, що створюють цінність, які він набуває.

Враховуючи складний та надзвичайно специфічний характер морської галузі, оцінку бізнесу цієї сфери господарювання необхідно проводити 3 врахуванням особливостей морського транспорту та його продукції. Навіть в різних сферах морського транспорту є значні особливості. Зокрема, продукцією стивідорної компанії $€$ перевантаження вантажів на території порту; судноплавної компанії - перевезення вантажів на морських суднах; сервісних компаніях надання послуг по організації переве- 
зення вантажу, заходу судна у порт, підбір екіпажу судна тощо. Як бачимо, ці підприємства здійснюють зовсім різні бізнес-процеси, для яких їм потрібні різні ресурси. Все це повинно враховуватися у процесі оцінки, що обумовлює актуальність теми статті.

Огляд останніх досліджень та публікацій. $Є$ багато праць які описують процес оцінки бізнесу. Навіть $€$ онлайн калькулятори 3 оцінки бізнесу, [9], де потрібно обрати сферу бізнесу, термін роботи, вказати нерухомість, деякі фінансові показники та інше й за цими даними он-лайн буде розрахована вартість бізнесу. Звичайно ці результати не можна брати за основу при прийнятті важливих рішень. Ці розрахунки занадто усереднені, щоб надати реальні результати оцінки вартості компанії.

У більшості робіт вказується, що основна мета процесу оцінки виявити критично важливі області бізнесу, що створюють цінність $[2 ; 7$; 8]. Не менш важливо визначити які області бізнесу є більш цінними, але лише за умови врахування мети оцінки. Наприклад, в залежності від мислення і цілей інвестора, його інтерес може полягати не стільки в прибутковості бізнесу, скільки в частці ринку, стратегічному позиціонуванні або спеціалізованій області ланцюжка створення вартості компанії. Результат оцінки потім розглядається як значуща оцінка діапазону значень, який буде ключовою точкою при узгодженні остаточної ціни бізнесу. Таким чином, результати оцінки важливі не тільки для визначення ключових факторів прибутку бізнесу, але також встановлення точки для майбутніх переговорів по угоді [14].
Особливості оцінки бізнесу у морській галузі наведені у роботах [3; 10; 11]. Зокрема, у статті [3] розглядається перспективність і зміст оцінки бізнесу як сучасного підходу до оцінки ефективності функціонування підприємств i їх об'єднань на прикладі морського транспорту України.

У статті [11] досліджено методичні основи оцінки вартості об'єктів власності, а також відображено проблеми існуючих підходів до оцінки об'єктів власності в морських портах. Наведений перелік етапів оцінки вартості цілісних майнових комплексів в порту та визначений зв'язок між об'єктом оцінки в порту, мети оцінки i вибору методичного підходу

Особливості оцінки нерухомого майна у портах та гідротехнічних споруд 3 використанням трьох методичних підходів в оцінці розглядаються у роботі [10]. Там вказуються особливості застосування підходів 3 точки зору формування вартості майна, впливу правових обмежень та враховуючи специфіку майна в порту.

Питання оцінки гідротехнічних споруд також розглядаються у роботі [12], де наводяться випадки оцінки інженерних споруд, розглядається зміст визначення інженерні споруди відповідно до визначення Державного класифікатора будівель та споруд, визначаються особливості ідентифікації суттєвих характеристик інженерних споруд, досліджуються особливості вибору бази оцінки при визначенні вартості інженерних споруд, та наводяться особливості вибору підходів та методів оцінки інженерних споруд.

Вказується на проблеми адміністративного впорядкування споруди 3 точки зору нагляду за іiі безпечною та надійною експлуатацією, 
тому що «... Правила технічної експлуатації річкових портових гідротехнічних споруд та Правила технічної експлуатації портових гідротехнічних споруд $\epsilon$ формально різними документами, тобто режим експлуатації технічно та функціонально аналогічних об'єктів може суттєво відрізнятись в залежності від їх адміністративного підпорядкування» [12. С. 3] .

Тобто, в окремих випадках досліджується оцінка майна в портах але практично повністю відсутні особливості оцінки вартості підприємств берегового сервісного обслуговування у морській галузі.

Завдання дослідження. Метою роботи є дослідження цілей та методів оцінки вартості бізнесу в різних сферах морської галузі 3 врахуванням специфіки їх господарювання.

Основний матеріал дослідження. Оціночна діяльність в Україні строго регламентована і регулюється багатьма нормативно-правових актив: закон, національні стандарти, положення тощо. Здійснювати оцінку може суб'єкт оціночної діяльності: суб'єкти господарювання або деякі органи державної влади [4] .

За даними Фонду держмайна України [6] станом на 04.09.2020 року відповідно до Державного реєстру оцінювачів та суб'єктів оціночної діяльності в Україні функціонують 2692 суб'єкти оціночної діяльності. У 2019 році їх кількість складала 2788, а в 2018 році - 2847 суб'єкти. Інформація про кількість оцінювачів в розрізі галузей, зокрема в морській галузі, відсутня. Подібна статистика не ведеться.

Відповідно до Національного стандарту № 1 «Загальні засади оцінки майна i майнових прав» «...біз- нес - певна господарська діяльність, яка провадиться або планується для провадження 3 використанням активів цілісного майнового комплексу» [5]. Цілісними майновими комплексами (ЦМК) в свою чергу є підприємства, а також їх структурні підрозділи (цехи, виробництва, дільниці тощо), які можуть бути виділені в установленому порядку в самостійні об'єкти 3 подальшим складанням відповідного балансу і можуть бути зареєстровані як самостійні суб'єкти господарської діяльності. Їх оцінка регламентується Національним стандартом № 3 «Оцінка цілісних майнових комплексів», але ЦМК не є синонімом бізнесу, а може бути лише його складовою.

В роботі [1] автор розглядає поняття оцінки бізнесу як об'єкту оцінки у відповідності до представлення цього поняття у вітчизняній нормативно-правовій базі та доходить висновку, що неприпустимим $є$ ототожнення понять бізнес, цілісний майновий комплекс та підприємство. Він вказує, що «... бізнес особливе явище, він може вміщувати не одну фірму або підприємство, а може вестись взагалі без створення юридичної особи. Найчастіше бізнес об'єднує декілька підприємств, іноді не має майнового комплексу, не використовує найманого труда та ін., але 3 врахуванням зовнішніх зв'язків, напрацьованих 3 роками, має окрему цінність» [1. С. 311] .

Оцінка вартості бізнесу - це розрахунок і обгрунтування вартості в грошовому вираженні на певну дату. В загальному вигляді оцінка вартості бізнесу залежить від цілей i, відповідно, виду вартості, економічних умов, в яких знаходиться бізнес, його 
РОЗВИТОК МЕТОДІВ

УПРАВЛІННЯ ТА ГОСПОДАРЮВАННЯ

НА ТРАНСПОРТІ, № 4 (73), 2020 стану та обсягу прав на оцінюваний бізнес [13].

Сьогодні на практиці оцінка бізнесу означає процес встановлення вартості підприємства як майна, яке приносить своєму власнику (або власникам) прибуток. Ця процедура викликана необхідністю дати інформацію власнику (або власникам) бізнесу для прийняття вірних управлінських рішень. За допомогою такої оцінки власник отримує точну інформацію про слабкі і сильні сторони своєї компанії, а також про резерви розвитку.

Процедура оцінки бізнесу передбачає аналіз декілька етапів, протягом яких виконується ретроспективний аналіз роботи компанії, аналіз всіх активів підприємства: рухоме та нерухоме майно, обладнання та устаткування, складські запаси, фінансові ресурси та нематеріальні активи. Структура майна компанії залежить від сфери діяльності. Зокрема, в стивідорних компаніях значна частка майна сформована за рахунок матеріальних активів: гідротехнічні споруди, спеціалізоване перевантажувальне устаткування, машини, обладнання, складські приміщення тощо. Схожа картина спостерігається при оцінці вартості судноплавної компанії, майно якої в основному сформовано 3 вартості судна. Слід підкреслити, що в цьому випадку мова йде про судноплавну компанію - власника судна. Якщо ж ми говоримо про компаніюоператора судна, то ситуація виглядає дещо інакше. Майно компанії буде складатися в основному 3 нематеріальних активів, до яких слід віднести кваліфікацію працівників та репутацію компаніі.
Подібна ситуація спостерігається також у більшості компаній 3 сектору берегового сервісного обслуговування: експедиторські, агентські, крюїнгові та брокерські компанії.

У випадку з логістичними компаніями важливим буде наявність у компанії власних складських приміщень, вартість яких може складати велику частину у вартості бізнесу.

За необхідності у деяких ситуаціях при оцінці бізнесу виконується розрахунок вартості активів і зобов'язань.

Поряд 3 аналізом якості роботи та минулих, поточних й майбутні доходах компанії, необхідно оцінити перспективи компанії на ринку та рівень иї конкурентоспроможності.

У результаті власник отримує компетентний висновок оцінювача про вартість свого бізнесу.

Оцінка бізнесу - це багаторівневий складний процес. Під час оцінки бізнесу необхідно провести ревізію та іноді переоцінити всі активи компанії і побудувати прогнози на певний часовий інтервал.

Перш ніж почати процес оцінки бізнесу, необхідно врахувати певні ключові фактори [7; 16].

1. Економічні фактори: рівень прибутковості та ризики. При оцінці бізнесу необхідно враховувати можливі альтернативні вкладення, особливо це стосується оцінки 3 метою купівлі-продажу. Інвестор обирає найкращий для себе варіант 3 більшим рівнем прибутковості та меншим рівнем ризику. У морській галузі 3 врахуванням іiі міжнародного характеру оцінка ринку здійснюється на глобальному ринку, тому необхідно враховувати не лише ризики, які притаманні національному ринку, а й 
ситуацію в інших країнах. Рівень прибутковості в морський галузі достатньо високий та приваблює інвесторів, але у деяких випадках глобальні ризики можуть здійснити негативний вплив на прийняття рішення про інвестування.

2. Політичні фактори: відсутність стабільної та прогнозованої ситуації у галузі. Вартість бізнесу багато у чому залежить від зовнішніх чинників і неринкових сил. В Україні зараз ми вимушені більше уваги зосередити на політичних змінах, ніж на дії ринкових економічних законів. Постійні кадрові зміни керівництва у Міністерстві інфраструктури, відсутність єдиної i зрозумілої для всіх стратегії розвитку галузі, вирішення питань у ручному режимі здійснює небажано великий вплив на економіку галузі, що одностайно знаходить відображення у оціночній діяльності і значно впливає на величину вартості компанії.

3. Соціальні фактори: особисті причини замовників та споживачів оцінки. Емоції чи неекономічні чинники можуть впливати на процес прийняття рішень i, отже, на результати процесу оцінки. Зокрема, якщо продавець вимушений продати свій бізнес у найкоротший термін, фактор часу матиме пріоритет над величиною вартості. Тому, дуже важливо розуміти, яким чином буда визначена вартість того або іншого бізнесу. Цей недолік можна нівелювати шляхом використання при оцінці більшого числа компаній аналогів, щоб отримати більш чітку картину вартостей схожих бізнесів.

4. Інформаційні фактори: для правильної оцінки потрібна достовірна інформація. Для отримання реальної вартості бізнесу необхідно використовувати реальну, сучасну та достовірну інформацію. Перш ніж розглядати можливість проведення оцінки і прогнозування майбутньої вартості, минулі і сучасні дані компанії повинні бути точними і правильними. Чим більше повну і докладну інформацію використовує оцінщик при розрахунках, тим краще будуть якість і точність результатів.

Необхідність оцінки вартості бізнесу виникає практично при всіх трансформаціях: при покупках і продажах підприємства, його акціонуванні, злиттях і поглинання, а також у багатьох інших ситуаціях.

Є ситуації, коли необхідність оцінки зазначена у законі [4; 5]. Зокрема у випадках:

- створення підприємств на базі державного майна;

- реорганізації, банкрутства, ліквідації державних підприємств;

- визначення вартості внесків учасників або виділення частки майна в якому є державна частка;

- переоцінки основних засобів для цілей бухгалтерського обліку;

- певні випадки оподаткування майна;

- визначення збитків або розміру відшкодування у випадках, встановлених законом;

- в інших випадках за рішенням суду або у зв'язку 3 необхідністю захисту суспільних інтересів.

В основному ці випадки стосуються оцінки майна державної власності. Для морських торговельних портів це актуально, тому що у випадку корпоратизації, або передачі державного майна на території морських торговельних портів приватним 
DEVELOPMENT OF MANAGEMENT

AND ENTREPRENEURSHIP METHODS ON TRANSPORT, № 4 (73), 2020
РОЗВИТОК МЕТОДІВ

УПРАВЛІННЯ ТА ГОСПОДАРЮВАННЯ

НА ТРАНСПОРТІ, № 4 (73), 2020 операторам, обов'язково необхідно визначити їх вартість. У випадку передачі в оренду або концесію портового перевантажувального комплексу (вантажного терміналу) приватному портовому оператору для визначення розміру орендної платні необхідно обов'язково виконати оцінку цього майна як окремого бізнесу, з метою визначення доходу, який він здатний приносити.

Існує багато інших ситуацій, коли не обов'язково, але бажано виконати оцінку $[1 ; 3 ; 7]$. Перелік найбільш поширених 3 них наведений нижче.

1. Купівля-продаж компанії. Ринкова ціна компанії при купівліпродажу формується у результаті співвідношення попиту і пропозиції. Попит визначає корисність компанії для покупця, а пропозиція - витрати на відтворення аналогічного підприємства для продавця.

Для великого бізнесу можлива ситуація продажу не всієї компанії, а iii частини. Наприклад, у стивідорній компанії можливо перевантажувальні комплекси (вантажні термінали) виділити у цілісні майнові комплекси та продавати, або здавати в оренду окремо. Також можливі варіанти виділення у самостійні підприємства непрофільні підрозділи, діяльність яких не пов'язана зі стратегічним положенням порту. До таких підрозділів можуть відносити ремонтно-механічні майстерні, автобази у портах, об'єкти соціального спрямування. Вони можуть бути продані стороннім особам, 3 якими потім укладаються підрядні договори.

Підприємства сервісної діяльності звичайно не є великими. Тому їх оцінку виконують як вартість повністю всього бізнесу.

2. Прийняття управлінських рішень. Ця мета не часто виділяється експертами окремо, але знання вартості власного бізнесу важливо для компанії. Це також важливо при реалізації великих проектів навіть без залучення інвесторів. Зміна вартості бізнесу у динаміці дозволить зробити висновок про ефективність проекту та зробити певні корегуючи кроки для покращення ситуації в компанії.

Окремо цю ситуацію слід брати до уваги власникам бізнесу, які прагнуть до залучення коштів у свої проекти. Інформація про вартість компаніï, особливо якщо ця вартість зростає в динаміці, свідчить про ефективний менеджмент та стабільність компанії, що є привабливим для інвесторів та партнерів.

3. Визначення розміру податку на майно компанії. В такому випадку замовником можуть виступати податкові органи. При цьому виникають відносини двох сторін: платника податків і держави в особі податкових органів, інтереси яких по суті своєї протилежні щодо розміру виплати податку. Платник податків, який зацікавлений у мінімізації податку, а податкові органи - у його максимізації. Для находження компромісу в рішенні даної проблеми можна залучати експертів - професійних оцінювачів. Це актуально при володінні коштовним майном: земля, будівлі, споруди. В окремих випадках логістичні компанії, які займаються складською логістикою, розташовують свої склади на територіях у спеціальних районах 3 метою зниження податкового навантаження. 
DEVELOPMENT OF MANAGEMENT

AND ENTREPRENEURSHIP METHODS ON TRANSPORT, № 4 (73), 2020
РОЗВИТОК МЕТОДІВ

УПРАВЛІННЯ ТА ГОСПОДАРЮВАННЯ

НА ТРАНСПОРТІ, № 4 (73), 2020
4. Страхування майна компаніiі. У процесі страхування обов'язково визначається страхова вартість майна, що знаходить відображення у визначенні розміру виплати за страховим договором за умови настання страхової події. Це вкрай актуально для компаній, які мають коштовне або унікальне обладнання. Усі без виключення морські судна застраховані. В порту практично все перевантажувальне устаткування застраховано. Власникам необхідно знати реальну вартість майна, щоб у випадку настання страхового випадку отримати компенсацію, яка дозволить швидко замінити пошкоджене майно.

Сьогодні страхові компанії пропонують безліч послуг. Можливо застрахувати випадок недоотримання прибутку, невиконання термінів виконання перевезення тощо.

Для підприємств сервісної діяльності коштовним активом можуть бути інформація та бази даних. Це майно складно оцінити та застрахувати, але можливо. Все залежить від зацікавленості власника у його збереженні. Страхові компанії пропонують страхування від кібер-ризиків та гарантують кібер-безпеку. В цьому випадку оцінщики повинні оцінити вартість нематеріальних активів компанії, які вона бажає застрахувати.

Для окремих компаній, наприклад, сюрвеєрських - найціннішим активом може бути спеціалізоване професійне устаткування, без якого компанія не зможе працювати. Інколи страхові компанії надають спеціальні пакети «страхування перевезень», в яких може бути застрахований вантаж, транспортні засоби тощо.
5. Отримання кредиту. Оцінка вартості компанії може бути потрібна також для визначення величини застави. Ця оцінка розглядається як кредитна вартість іiі активів і відповідає ринковій вартості застави цієї компанії, яку кредитор може одержати після продажу компанії у випадку іï неплатоспроможності. Тобто, це сума коштів, що сподівається одержати кредитор від продажу компанії у випадку іï банкрутства.

Враховуючи той факт, що у більшості підприємств сервісної діяльності морської галузі основні активи $є$ нематеріальними, то ймовірність отримання кредиту під заставу дуже мала.

6. Інвестування. Відповідно до міжнародних стандартів оцінки під інвестиційною вартістю розуміється суб'єктивне поняття, що співвідносить конкретний об'єкт власності 3 конкретним інвестором або групою інвесторів, що мають певні цілі й (або) критерії інвестування. Тобто, інвестиційна вартість - це здатність інвестицій приносити дохід або віддачу і $є$ характеристикою інвестиційного проекту [2].

При оцінці цієї ситуації визначаються, в першу чергу, майбутні доходи, тому що з точки зору бізнесу усі компанії виробляють один й той же продукт - гроші. Тому, інвестор зацікавлений у отриманні прибутку, а визначити їх можна лише спрогнозувавши доходи на основі аналізу роботи компанії у попередні періоди.

Морська галузь є дуже динамічною, тому інвестування у підприємства цієї галузі здійснюється дуже активно. Тому, щоб продемонструвати інвестиційну привабливість ком- 
панії для потенційних інвесторів, слід виконати оцінку вартості бізнесу.

Існують інші ситуації, в яких потрібна оцінка вартості компанії, наприклад, реорганізація (злиття, поглинання, ліквідація), викуп акцій у акціонерів, продаж частки у компанії, тощо. Всі вони не є достатньо затребуваними в морській галузі, тому ми не будемо розглядати їх докладніше.

У науковій літературі більша частина авторів виділяє певні методи оцінки, які в різних джерелах можуть мати різну назву, але зміст їх однаковий.

Наприклад, у роботі [16] до найбільш поширених методів оцінки, що використовуються в інвестиційному банкінгу, при оцінці діючого бізнесу галузеві практики використовують наступні три основні:

- аналіз дисконтованого грошового потоку;

- аналіз порівнянних компаній;

- прецедентні операції (рис. 1).

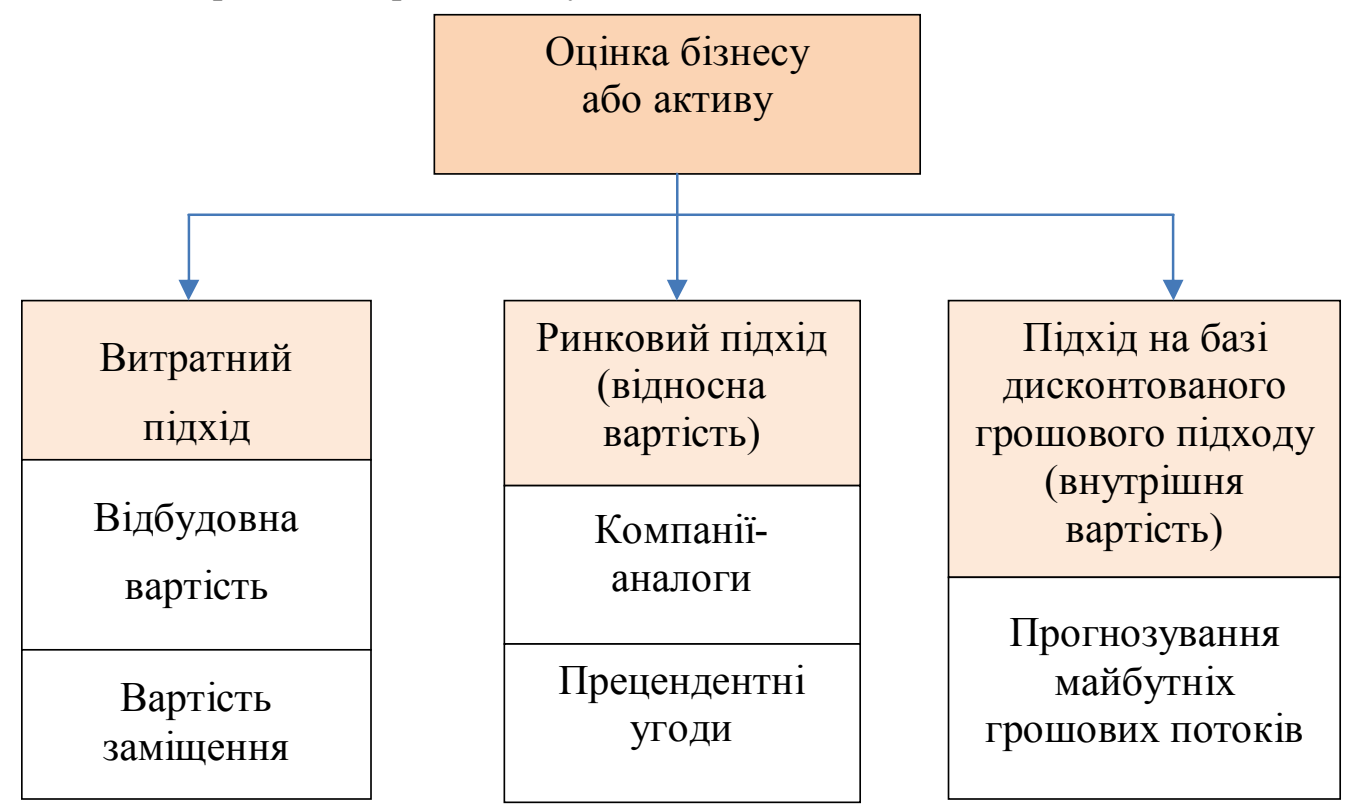

Джерело: [16].

Рис. 1. Методи оцінки бізнесу

Проведене дослідження теоретичних робіт, нормативно-правової бази та практичних прикладів у закордонній та вітчизняній практиці показало, що методи оцінки бізнесу представлені трьома основними підходами, у яких бізнес розглядається 3 різних боків:

- витратний підхід;
- дохідний підхід;

- порівнянний підхід.

Кожний із цих підходів може бути реалізований різними методами. Як правило, щоб одержати дійсно реальну оцінку, застосовують всі три підходи, а потім проводять обгрунтування єдиного значення оцінки компанії. 
DEVELOPMENT OF MANAGEMENT

AND ENTREPRENEURSHIP METHODS ON TRANSPORT, № 4 (73), 2020
РОЗВИТОК МЕТОДІВ

УПРАВЛІННЯ ТА ГОСПОДАРЮВАННЯ

НА ТРАНСПОРТІ, № 4 (73), 2020
Розглянемо деякі методи 3 різних підходів та наведемо ситуації, у яких слід використовувати кожен метод 3 врахуванням специфіки морської галузі.

1. Витратний підхід. Базується на визначені витрат, які понесе підприємство для відбудови певного майна. Це базовий підхід, який використовуються податковими органами для визначення вартості майна для визначення обсягу податкових платежів на майно. Також методи цього підходу використовуються при кредитуванні, щоб визначити можливу вартість майна у випадку продажу при втраті платоспроможності боржника.

В цьому підході використовуються різні методи, зокрема:

- метод чистої балансової вартості - найбільш простий метод оцінки активів компанії на базі інформації з основних форм бухгалтерської звітності. Використовується не часто, зазвичай лише як додатковий метод;

- метод скоректованої балансової вартості - більш удосконалений метод оцінки ніж попередній, враховує зміну балансової вартості майна компанії у результаті переоцінки. Його можна використовувати для великих компаній 3 великою кількістю майна;

- метод вартості заміщення оцінка витрат на повне заміщення активів компанії при збереженні іiі господарського профілю, цей метод орієнтований тільки на оцінку матеріальних активів i прийнятний для стивідорних компаній, судноплавних компаній та інших підприємств, які мають значну кількість основних засобів;

- метод відбудовної вартості розраховують всі витрати, які необ- хідні для створення точної копії оцінюваної компанії, на відміну від попереднього. Цей метод дозволяє врахувати вартість нематеріальних активів, таких як авторські права, патенти, комп'ютерні програми, що важливо для більшості підприємств сервісного берегового обслуговування.

Методи витратного підходу при оцінці бізнесу використовуються лише для можливості оцінити вартість майна. Наприклад, витратний підхід $є$ переважно основним при оцінці інженерних (у тому складі берегоукріплюючих гідротехнічних) споруд, на відміну від оцінки будівель, що суттєво підвищує вимоги до збору вихідних даних, обгрунтування та проведення всього комплексу необхідних оціночних процедур [12].

2. Дохідний підхід. Основою цього підходу є врахування доходів, як поточних, так і майбутніх. Методи цього підходу $\epsilon$ самими популярними при оцінці бізнесу не лише в морській галузі, а й і в інших сферах господарювання. Доходи компанії враховуються як при купівлі-продажу, так і при залученні інвесторів до компанії.

Також цей підхід є основою при прийнятті управлінських рішень, при оцінці діяльності керівництва компанії. Особливо це актуально у тому випадку, коли керівництво компанії не входить до їі менеджменту.

В рамках цього підходу використовуються наступні методи:

- метод капіталізації чистого доходу - враховується потік доходу, який перетворюється в поточну вартість шляхом застосування норми капіталізації. Складність визначення норми капіталізації міститься у від- 
РОЗВИТОК МЕТОДІВ

УПРАВЛІННЯ ТА ГОСПОДАРЮВАННЯ

НА ТРАНСПОРТІ, № 4 (73), 2020 сутності активного, прозорого ринку продажу бізнесів. Недостатність актуальної інформації по саме продажам в морській галузі ускладнює використання цього методу на практиці;

- метод капіталізації дивідендів - звичайно застосовується для оцінки компанії, акції якої котуються на відкритому фондовому ринку. Цей метод неактуальний для морської галузі України;

- метод дисконтованих грошових потоків - найбільш популярний метод із всіх наведених 3 усіх підходів. Цей метод дозволяє більш реально оцінити майбутній потенціал підприємства. У якості дисконтованого доходу використовується або чистий дохід, або грошовий потік.

3. Порівняльний підхід. Методи цього підходу можна активно використовувати лише при наявності у відкритому доступі інформації про роботу, стан та фактичні вартості багатьох бізнесів у цій же сфері господарювання. Це дозволить обрати компанії, які схожі за розмірами та видами діяльності і були продані у близькі моменти часу.

Щоб оцінити бізнес за допомогою цього підходу необхідно вивчити галузь, до якої він належить. За кордоном існують дослідницькі організації, які збирають та публікують інформацію по галузевих коефіцієнтах, якими користуються для оцінки бізнесу. Однак підприємства групуються й рівняються не тільки по галузевій ознаці. Оцінюваний бізнес порівнюється 3 іншими за розмірами підприємства, стадією життєвого циклу, стратегії поведінки на ринку тощо.
Порівняльний підхід передбачає використання наступних методів:

- метод порівнянних продажів - він міститься в аналізі ринкових цін на компанії-аналоги. При цьому в моделі розглядають компанії, які повинні належати тій же галузі, бути схожими за розміром та організаційно-правовою формою. Коректування ринкової ціни змодельованої компанії-аналога проводять по найбільш важливих позиціях: дата створення, дата продажу, галузь, тип бізнесу, організаційно-правова форма, кількість працівників, площа виробничих та адміністративних приміщень тощо. Цей метод $є$ основним при оцінці вартості нерухомості (квартири, будинку тощо). Його можна використовувати для оцінки окремих об'єктів у складі компанії, але оцінити бізнес за його допомогою практично неможливо внаслідок відсутності у відкритому доступі такого великого масиву внутрішніх даних про декілька схожих компаній, які були продані у недавній момент часу;

- метод мультиплікаторів для одержання достовірного результату проводять ретельний аналіз фінансового стану компаній-аналогів, який складається 3 визначення структури капіталу, темпів росту компанії, коефіцієнтів рентабельності, ліквідності, платоспроможності та ділової активності. Аналізуються також дані про дохід компаній за останні п'ять років. Для кожної компані-аналога визначаються мультиплікатори, за якими виконується оцінка. Розраховується середнє арифметичне та визначається ціна бізнесу, який оцінюється. Цей метод дуже складний у використанні в умовах морської 
галузі України за причинами, які вже наводилися вище: немає достовірної інформації, відсутній активний ринок продажу бізнесів тощо.

Хоча метод дисконтованих грошових потоків $є$ найбільш популярним методом оцінки бізнесу, для більшості підприємств деяка комбіна-ція методів оцінки бізнесу буде найсправедливішим способом визначити вартість [15].

Традиційно передбачається, що у звіті про оцінку професійний оцінщик повинний навести результати оцінки вартості майна, яка розрахована за допомогою використання методів всох трьох підходів, або обгрунтувати неможливість використання якогось 3 підходів. В морській галузі важливо залучити до оцінки бізнесу кваліфікованого спеціаліста, який $\epsilon$ професіоналом в оціночній діяльності, має всі необхідні сертифікати та розуміється на специфіці діяльності морської галузі. Він зможе запропонувати кращі методи, які слід використовувати для визначення вартості, щоб можна було досягти мети оцінки.

Висновки. Оцінка бізнесу - це важливий процес, який дозволяє визначити вартість бізнесу, спираючись на логічні розрахунки і числові аргументи.

Результати оцінки необхідні при розрахунку орендної платні, отриманні кредиту, прийнятті управлінського рішення, залученні інвестицій тощо. Розрахована вартість не $\epsilon$ догмою, але може стати демонстрацією прибуткового стану компанії, ефективного менеджменту та перспектив розвитку.
Правильно виконана оцінка це ще й моніторинг роботи компанії та переоцінка вартості майна. Тому, перш ніж розглядати будь-який 3 методів оцінки, важливо переконатися, що фінансові дані, які використовуються для оцінки, є повними, актуальними і точними. Тільки $з$ достовірними даними і правильно спланованим стратегічним підходом можна зробити надійний прогноз. Чим повніше i детальніше будуть дані для аналізу, тим точніше i якісніше будуть результати оцінки.

Визначення вартості бізнесу $\epsilon$ комплексним процесом, який вимагає врахування ряду факторів і аналіз фінансового стану бізнесу. Оскільки цей процес складний, рекомендуємо власникам бізнесу залучати до оцінки професіоналів, щоб отримати об'єктивну i реальну оцінку вартості їх бізнесу.

Найбільш поширеними методами оцінки $\epsilon$ так званий метод дисконтованого грошового потоку, основна перевага якого полягає в його здатності вимірювати майбутні результати вже сьогодні. Це складний експертний метод, але саме він надає інформацію не лише про поточний стан компанії, а й про його перспективи.

При оцінці бізнесу в морській галузі треба брати до уваги існуючи методи та підходи, але бізнес як об'єкт оцінки потребує іншого сполучення традиційних методів доходного, порівняльного та витратного підходів, та використання конкретних методів оцінки саме бізнесу й з врахуванням специфіки господарювання окремих секторів морської галузі. 


\section{СПИСОК ЛІТЕРАТУРИ}

1. Бачевський Б.С., Заблодська І.В., Решетняк О.О. Потениіал і розвиток підприємства: Навч. посібник. Київ. 2009. 400 с.

2. Валдайцев С.В. Оченка бизнеса и управление стоимостью предприятия. Москва. 2001. 720 с.

3. Гребенник Н.Г., Сочинский М.С. Современные подходы к оченке эффективности функционирования субъектов хозяйственной деятельности // Економічні інновачії. Організація, економіка $i$ управління основною експлуатаційною діяльністю транспортного комплексу. Зб. наук праџь. 2011. Bun. 46. C. 118-125.

4. Закон Украӥни «Про оиінку майна, майнових прав та професійну оиіночну діяльність в Україні» №2658-III від 12.07.2001 p. URL: https:// zakon.rada.gov.ua/laws/show/2658-14\#Text (дата звернення: 15.10.2020)

5. Наиіональний стандарт № 1 «Загальні засади оиінки майна і майнових прав». Затверджено постановою Кабміна Украӥни № 1440 від 10.09.2003 p. URL: https://zakon.rada.gov.ua/laws/show/1440-2003-\%D0\% BF\#Tехt (дата звернення: 15.10.2020)

6. Офіційний сайт Фонду державного майна Украйни. URL: http://www. spfu.gov.ua/ua/content/spf-estimate-registers.html (дата звернення: 23.10.2020)

7. Оченка бизнеса: Учебник / Под ред. А.Г. Грязновой, М.А. Федотовой. Москва. 2002. 512 c.

8. Оиенка имущества и имущественных прав в Украине / Под ред. Н.П. Лебедь. Київ. 2003. 715 c.

9. Оиенка стоимости бизнеса онлайн URL: http://bizrating.com.ua/ calculator (дата звернення: 16.10.2020)

10. Сочинский М.С. Особливості застосування методичних підходів до оиінки нерухомого майна та гідротехнічних споруд портів // Матеріали 65-ої науково-технічної конференції ОНАЗ. 2010. С. 115-118.

11. Сочинський М.С., Швеиь І.С. Очінки майна у морських торговельних портах України // Розвиток методів управління та господарювання на транспорті. 2017. № 3 (60). C. 46-58.

12. Суліменко Ю. Деякі особливості оџінки інженерних споруд сторінка 1 з 14 деякі особливості оцінки інженерних споруд URL: http://www. afo.com.ua/doc/Dejaki_osoblivosti_otsinki_inzhenernikh_sporud.pdf (дama звернення: 18.10.2020)

13. How to value a company? The business valuation process. URL: https:// www.onetoonecf.com/the-usefulness-of-the-business-valuation-process (dama звернення: 27.10.2020)

14. Seth David. 7 Business Valuation Methods. URL: https://www.fundera.com/ blog/business-valuation-methods (дата звернення: 25.10.2020) 
15. Susan Ward. 3 Business Valuation Methods. URL: https://www.thebalance. com/business-valuation-methods-2948478 (дата звернення: 25.10.2020)

16. What are the Main Valuation Methods? URL: https://corporatefinance institute.com/resources/knowledge/valuation/valuation-methods/

(dama звернення: 24.10.2020)

\section{REFERENCES}

1. Bachevskiy, B.Ye, Zablodska, I.V. \& Reshetnyak, O.O. (2009). Potentsial i rozvitok pidpriemstva [Potential and Development Company]: Navchalniy posibnik. Kï̈v. 400 p. [in Ukrainian]

2. Valdaytsev, S.V. (2001). Otsenka biznesa i upravlenie stoimostyu predpriyatiya. [Business valuation and enterprise value management]. Moskva. 720 p. [in Russian]

3. Grebennik, N.G. \& Sochinskiy, M.S. (2011). Sovremennye podkhody k otsenke effektivnosti funktsionirovaniya subektov khozyaystvennoy deyatelnosti [Modern approaches to assessing the effectiveness of the functioning of economic entities]. Yekonomichni innovatsii. Organizatsiya, ekonomika $i$ upravlinnya osnovnoyu ekspluatatsiynoyu diyalnistyu transportnogo kompleksu - Economic innovations. Organization, economy and management of the main operational activities of the transport complex. P. 118-125 [in Russian]

4. Zakon Ukrä̈i «Pro otsinku mayna, maynovikh prav ta profesiynu otsinochnu diyalnist $v$ Ukraïni» [The Law of Ukraine "On the assessment of property, property rights and professional valuation activities in Ukraine»] Retrieved from https://zakon.rada.gov.ua/laws/show/2658-14\#Text, accessed 15 October 2020 [in Ukrainian]

5. Natsionalniy standart № 1 «Zagalni zasadi otsinki mayna i maynovikh prav» zatverdzheno postanovoyu Kabmina Ukraïni [National standard № 1 «General principles of property valuation and property rights»] Retrieved from https://zakon.rada.gov.ua/laws/show/1440-2003-\%D0\%BF\#Text. accessed 15 October 2020 [in Ukrainian]

6. Ofitsiyniy sayt Fondu derzhavnogo mayna Ukraïni. [Official site of the State Property Fund of Ukraine]. Retrieved from http://www.spfu.gov.ual ua/content/spf-estimate-registers.html accessed 23 October 2020 [in Ukrainian]

7. Gryaznova, M.A. (2002). Otsenka biznesa [Business evaluation]. Moskva. 512 p. [in Russian]

8. Lebed, N.P. (2003). Otsenka imushchestva i imushchestvennykh prav v Ukraine [Valuation of property and property rights in Ukraine]. Kï̈. 715 p. [in Russian]

9. Otsenka stoimosti biznesa onlayn [Online business valuation] Retrieved from http://bizrating.com.ua/calculator/_accessed 16 October 2020 [in Ukrainian] 
10. Sochinskiy, M.S. (2010). Osoblivosti zastosuvannya metodichnikh pidkhodiv do otsinki nerukhomogo mayna ta gidrotekhnichnikh sporud portiv [Features of application of methodical approaches to an estimation of real estate and hydraulic engineering constructions of ports] Materiali 65-oï naukovotekhnichnoï konferentsiï ONAZ. P. 115-118 [in Ukrainian]

11. Sochinskiy, M.S. \& Shvets, I.S. (2017). Otsinki mayna u morskikh torgovelnikh portakh Ukrä̈ni [Property valuation in commercial sea ports of Ukraine]. Rozvitok metodiv upravlinnya ta gospodaryuvannya na transporti - Development of management and entrepreneurship methods in transport. № 3 (60). P. 46-58 [in Ukrainian]

12. Sulimenko, Yu. (2017). Deyaki osoblivosti otsinki inzhenernikh sporud [Some features of the assessment of engineering structures]. Retrieved from http://www.afo.com.ua/doc/Dejaki_osoblivosti_otsinki_inzhenernikh_sporud. pdf accessed 18 October 2020 [in Ukrainian]

13. How to value a company? The business valuation process. Retrieved from https://www.onetoonecf.com/the-usefulness-of-the-business-valuationprocess/ accessed 27 October 2020

14. Seth David. 7 Business Valuation Methods. Retrieved from https://www. fundera.com/blog/business-valuation-methods accessed 25 October 2020

15. Susan, Ward. 3 Business Valuation Methods. Retrieved from https://www. thebalance.com/business-valuation-methods-2948478 accessed 25 October 2020

16. What are the Main Valuation Methods? Retrieved from https://corporate financeinstitute.com/resources/knowledge/valuation/valuation-methods/ accessed 24 October 2020

Стаття надійшла до редакиії 23.11.2020

Посилання на статтю: Гребенник Н.Г., Восканян Е.Г. Цілі та методи оцінки бізнесу в морській галузі // Розвиток методів управління та господарювання на транспорті: Зб. наук. праць, 2020. № 4 (73). C.92-107. DOI 10.31375/2226-1915-2020-4-92-107.

Article received 23.11.2020

Reference a JournalArtic: Grebennyk, Natalia\& Voskanian, Emma. (2020). Objectives and methods of business valuation in the maritime industry // Development of management and entrepreneurship methods on transport. 4 (73), 92-107. DOI 10.31375/2226-1915-2020-4-92-107. 